\title{
Allogeneic Transplants of Rib Cartilage Preserved in 98\% Glycerol or 70\% Alcohol into the Malar Process of Rats: A Comparative Histological Study
}

\author{
Eduardo Hochuli VIEIRA ${ }^{1}$, Marisa Ap. Cabrini GABRIELLI ${ }^{2}$, \\ Tetuo OKAMOTO ${ }^{2}$, Mario Francisco Real GABRIELLI ${ }^{2}$, \\ Jose Scarso FILHO ${ }^{2}$, Lizeti O. T. RAMALHO ${ }^{3}$, Celso E. de \\ Moraes BARBOSA ${ }^{2}$ and Elcio MARCANTONIO ${ }^{2}$
}

(Received 17 February and accepted 9 December 1992)

Key words: graft, cartilage, glycerol preservation, alcohol preservation

\begin{abstract}
A comparative study was made of two methods of cartilage preservation, $98 \%$ glycerol and $70 \%$ alcohol. Rib cartilage was treated by either of these methods and transplanted into the malar proccess of rats. Cartilage grafts preserved by both methods were equally well tolerated. Resorption and bone substitution were similar in both groups after 120 days, although resorption was greater for the alcohol-preserved cartilage up until day 30 . The possible reduction in antigenicity by the $98 \%$ glycerol did not produce any difference of behavior from the cartilage preserved in $70 \%$ alcohol.
\end{abstract}

\section{Introduction}

Because of the low antigenicity of cartilage, drastical chemical methods are usually not required for its preservation in cartilage grafts. Moderately aggressive methods of preservation suffice, eliminating the need for special storage equipment ${ }^{[1]}$.

Allogeneic cartilage preserved in Ringer's solution at $3^{\circ} \mathrm{C}^{[2]}$, or devitalized and frozen cartilage $^{[3]}$, implanted in edentulous human alveolar ridges, is well tolerated, and absence of inflammation has been found in clinical, radiological and histopathological evaluations ${ }^{[2,3]}$.

Allogeneic cartilage transplants preserved by immersion in thiomerosal or $70 \%$ ethanol and refrigerated, as well as freeze-dried specimens, show similar results to autogenous grafts, with a mild initial foreign body reaction, followed by progressive resorption and invasion by fibrous connective tissue ${ }^{[4]}$. Human cartilage preserved in thimerosal and transplanted to the nasal septum was reported to be stable and morphologically acceptable after 31 to 33 months, suggesting fibrous union. Preserved costal cartilage transplanted to the facial middle third in humans shows a greater tendency for ossification than autogenous material ${ }^{[5]}$.

Preservation of cartilage in $98 \%$ glycerol $^{[6]}$ and $70 \%$ alcohol ${ }^{[7,8]}$ are two inexpensive methods that do not require special equipment for transportation and storage.

Glycerol removes intracellular water without altering the ionic concentration, and functions as an efficient protector of cellular integrity during freezing ${ }^{[9]}$. It has been used to preserve human dura mater used in cardiac surgery ${ }^{[10-14]}$ and also corneas ${ }^{[15]}$.

Comparison of fresh autogenous cartilage with glycerol-preserved cartilage when trans-

\footnotetext{
1 Scholarship from FAPESP

2 Oral and Maxillofacial Surg., Dental School at Araraquara

3 Histology Division, Dental School at Araraquara

To whom all correspondence should be addressed: Dr. Eduardo Hochuli VIEIRA, Faculdade De Odontologia De Araraquara Rua Humaitá, 1680, Araraquara, S. P., BRASIL, 14800
} 
planted into the malar process of rats showed comparable inflammatory reactions. The preserved material underwent faster substitution by bone ${ }^{[6]}$. Allogeneic transplants preserved in glycerol undergo faster substitution by bone than preserved autogenous material ${ }^{[16]}$. Removal of the perichondrium enhances substitution of the preserved material ${ }^{[17]}$.

Transplantation of auricular cartilage preserved in $70 \%$ alcohol into surgically created periodontal defects in monkeys showed similar results to fresh autogenous and allogeneic grafts, the osteogenesis being proportional to the period of preservation ${ }^{[18]}$. Human nasal cartilage preserved in $70 \%$ alcohol suffers faster resorption and bone formation than autogenous grafts ${ }^{[4,7]}$.

Since both approaches have their respective clinical applications, the present study was performed to compare the behavior of allogeneic cartilage preserved by these methods.

\section{Materials and Methods}

Seventy-five male albino rats (Rattus norvegicus, albinus, wistar) were used in the present investigation. The animals weighed 300 to $350 \mathrm{~g}$ and were fed a solid diet during the whole experimental period, except for the first $24 \mathrm{~h}$ postoperatively, and water ad libitum.

Graft harvesting

After induction of general anesthesia by intraperitoneal injection of $10 \%$ chloral hydrate (Quimibrás Produtos Químicos S/A) at a dose of $0.4 \mathrm{mg} / 110 \mathrm{~g}$ body weight, the thoracic region was depilated.

With the animal positioned ventral side uppermost on a surgical table, access to the three last ribs was obtained by a skin incision and divulsion of the subcutaneous tissues, using medium straight scissors. To remove the costal segment, it was isolated with a skin hook, facilitating the removal of adherent fascia and muscle before separation of the segment.

The remaining debris still left on the costal segments was removed with a No. 15 blade. The cartilage was then separated. The perichondrium was removed with No. 11 and No. 15 scalpel blades under observation with a stereoscopic microscope. The three animals that had served as donors were then sacrificed.

The cartilage specimens were divided into two groups for preservation:

a) $70 \%$ alcohol-The cartilage was rinsed in sterilized physiological solution for $15 \mathrm{~min}$ and preserved in ethanol for 20 days under refrigeration.

b) $98 \%$ glycerol-The cartilage was rinsed in sterilized physiological solution for $15 \mathrm{~min}$ and preserved in glycerol for 20 days under refrigeration.

\section{Grafting procedure}

After induction of general anesthesia in the same manner as described above, with the animal positioned laterally on the table, the left infraorbital region was depilated. After disinfection with thimerosal, surgical access to the malar proccess was obtained through a skin incision with a No. 15 blade, made approximately $2.0 \mathrm{~mm}$ below the inferior orbital ridge, following its contour, with an approximate extension of $10.0 \mathrm{~mm}$.

After divulsion of the soft tissues with small acute straight scissors, the periosteum was also incised and reflected with a No. 7 wax spatula and a No. 2 Hollenback instrument. The soft tissues were kept retracted with two iridectomy forceps. Next, using a No. 702 low-speed bur (MAILLEFEK, Suiça.), a cavity was prepared in the bone, approximately $4.0 \mathrm{~mm}$ long with a width slightly more than the diameter of the bur. Intermittent irrigation with physiological saline was maintained. The approximate depth of the osteotomy was $2.0 \mathrm{~mm}$, taking care to expose both the cortical and medullary bone without perforating the malar process. After preparation of the host bed, it was thoroughly irrigated to remove debris.

The preserved graft material was divided into segments, which were adapted to their respective host beds. The periosteum was placed in its original position, and layered interrupted sutures were used to close the wounds with 5-0 polyvicryl (ETHICON.).

All animals received a single intramuscular dose of 160,000 iu Penicillin G Benzatine 
(BENZETACIL, Fontoura weyth.). They were then divided into two groups, according to the type of graft received, as follows:

a) GROUP I - Allogeneic transplants preserved in $70 \%$ ethanol under refrigeration, and hydrated for $5 \mathrm{~min}$ in sterile physiological saline before transplantation.

b) GROUP II-Allogeneic transplants preserved in $98 \%$ glycerol under refrigeration, and hydrated for $5 \mathrm{~min}$ in sterile physiological saline before transplantation.

\section{Histopathological Processing}

Six animals in each group were sacrificed after 5, 10, 20, 30, 60 and 120 days postoperatively, and the whole zygomatic arch removed from each. The specimens were fixed in formalin and decalcified in $50 \%$ sodium citrate and formic acid solution, following routine laboratory procedures. Semi-serial $6^{-} \mu \mathrm{m}$-thick sections were obtained and stained with hematoxylin-eosin for histological analysis.

\section{Results}

\section{$5 D A Y S$}

GROUP I (70\% ethanol)-The cartilage occupied the host bed without signs of resorption. Close to the material, blood clots were present in isolated areas. At other sites, small numbers of neutrophils and numerous macrophages were found. In one of the specimens, discrete resorption of chondrocytes was evident. In more distant areas, young fibroblasts and newly formed capillaries had appeared (Fig.1).

GROUP II (98\% glycerol)-The cartilage occupied the host bed without signs of resorption. The inflammatory infiltrate close to the material was comparable to that seen in the previous group. In most specimens, fibroblast proliferation at more distant sites was more intense in comparison with the alcohol-preserved material. Moderate capillary proliferation was also found (Fig.2).

\section{DAYS}

GROUP I - The cartilage was associated with well vascularized connective tissue showing intense fibroblast proliferation (Fig.3). Resorption of the graft was seen at some areas, which were invaded by proliferating connective tissue. Abundant newly formed bone and intense osteoblast proliferation appeared close to the osteotomy limits. Moderate numbers of macrophages and neutrophils were evident in the connective tissue near the graft.

GROUP II-The morphological characteristics resembled those in the previous group. However, in most cases, bone formation close to the osteotomy limits was more intense, and resorption of the cartilage was more discrete (Fig.4). Close to the graft, numerous macrophages and some lymphocytes were found.

\section{$20 \mathrm{DA} Y S$}

GROUP I - Extensive resorption of the cartilage was found in some specimens, so that approximately one half of the graft remained in the surgical cavity. Resorbed areas were filled either by bone or connective tissue without bone differentiation (Fig.5). Some macrophages and lymphocytes were observed in the connective tissue close to the graft.

GROUP II - In all specimens, bone formation was intense and partly filled the resorbed cartilage areas. Cartilage resorption was less pronounced than in the previous group (Fig.6). Usually, two-thirds of the graft remained in the host bed. The connective tissue without differentiation contained some macrophages and lymphocytes.

\section{$30 \mathrm{DA} Y S$}

GROUP I - The cartilage had undergone resorption in numerous areas, and less than half of the graft remained. At several sites, newly formed bone was in contact with the cartilage (Fig. 7). However, in some areas where the perichondrium had not been totally removed, a thin band of connective fibrous tissue separated the graft from the newly formed bone.

GROUP II-Resorption of the cartilage was less pronounced than in Group I . In most 


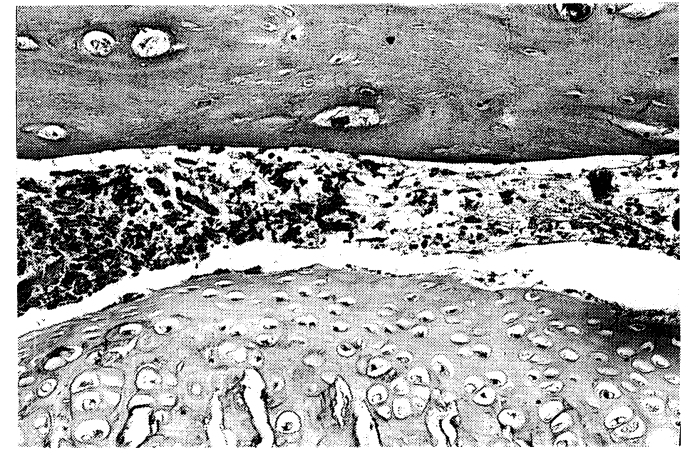

Fig. 1 Group I (alcohol)-5 days-Cartilage lined by connective tissue and bone wall of the host bed. H.E. x 160

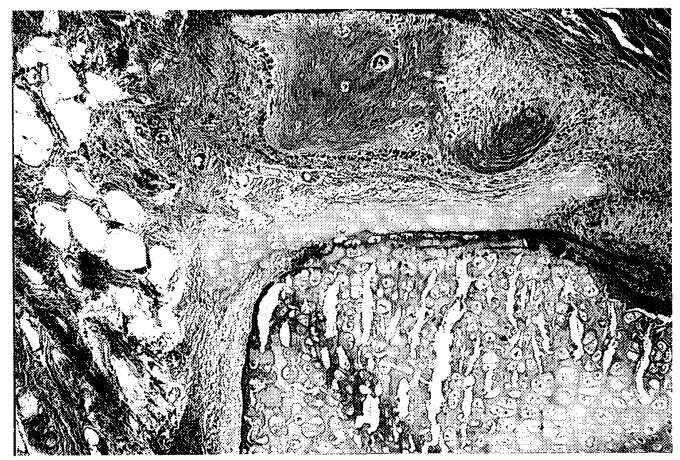

Fig. 3 Group I-10 days-Cartilage and invading connective tissue. H.E. x63

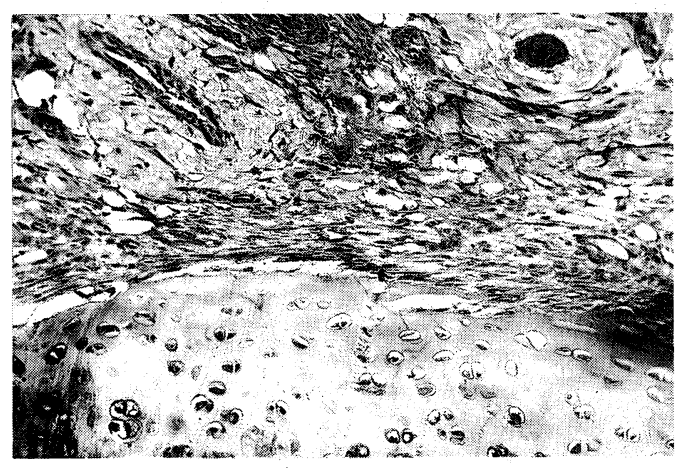

Fig. 2 Group II (glycerol)-5 days-Cartilage graft in position without resorption, surrounded by connective tissue and capillary proliferation. H.E. x160

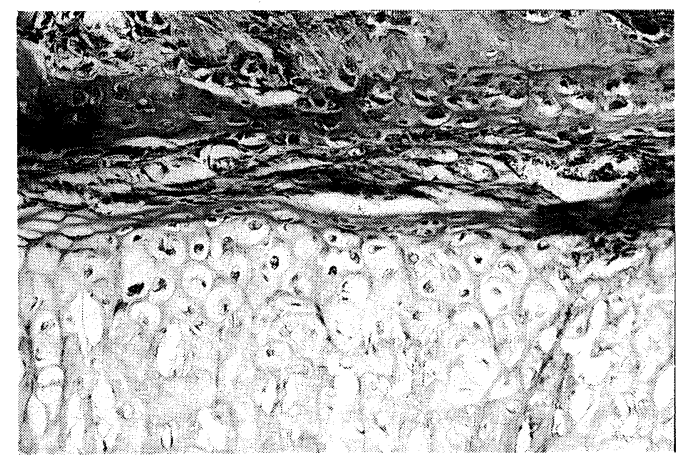

Fig. 4 Grop II-10 days-Cartilage and surrounding connective tissue. H.E. x160

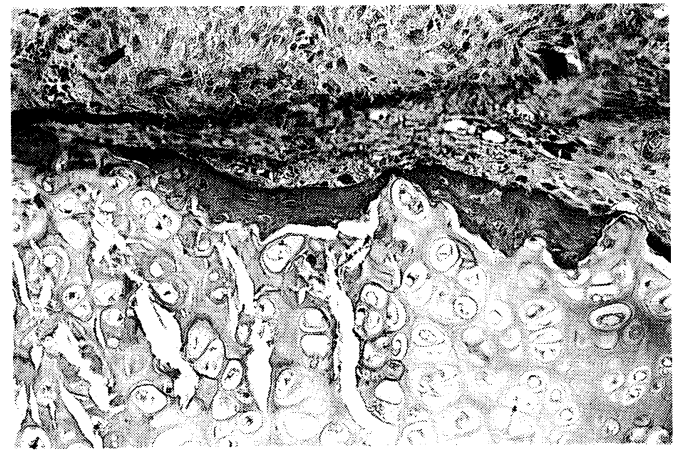

Fig. 5 Group I-20 days-Areas of resorption of cartilage with bone substitution. H.E. x160

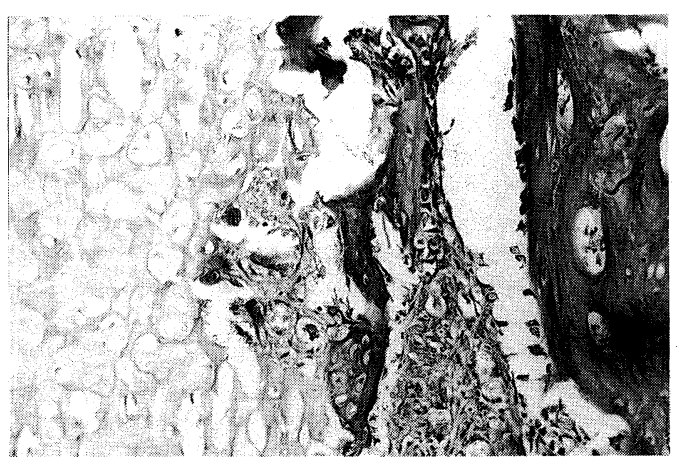

Fig. 6 Group II-20 days-Resorption of the transplanted cartilage. H.E. x160 


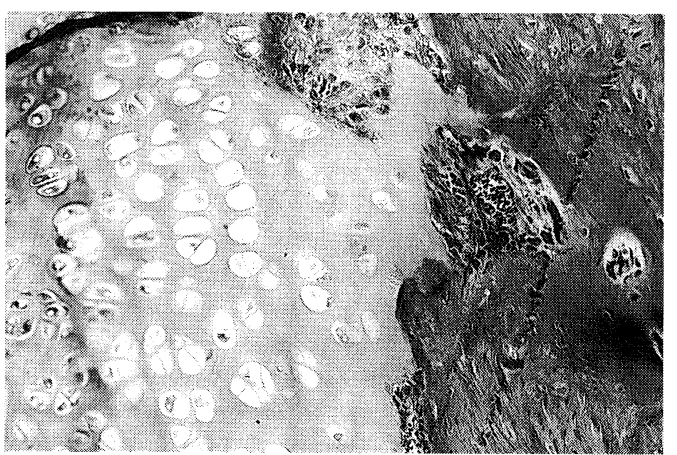

Fig. 7 Group I-30 days-Newly formed bone in close contact with the transplanted cartilage. H.E. $\times 160$

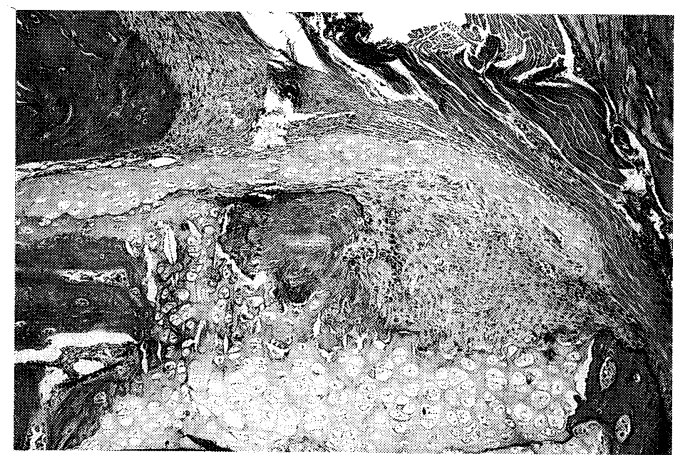

Fig. 9 Group I-60 days-Extensive resorption of the cartilage. H.E. x160

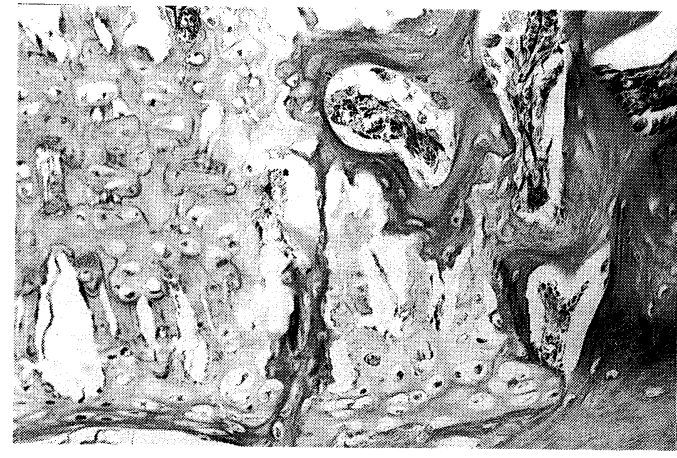

Fig. 8 Group II-30 days-Resorption of the grafted cartilage and newly formed bone. H.E. x160

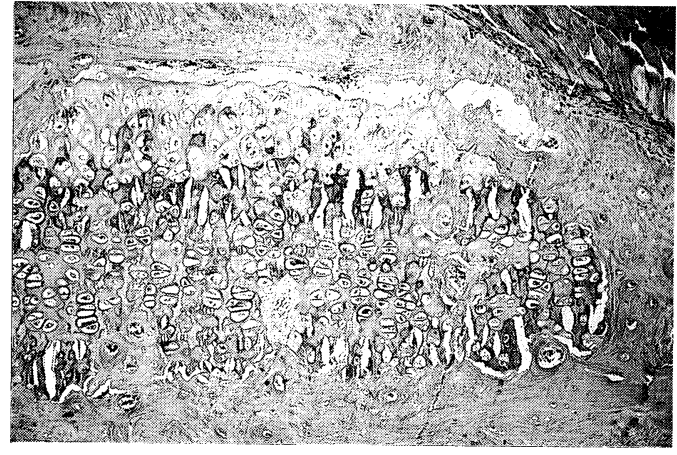

Fig. 10 Group II-60 days-Resorption of the cartilage. H.E. x63

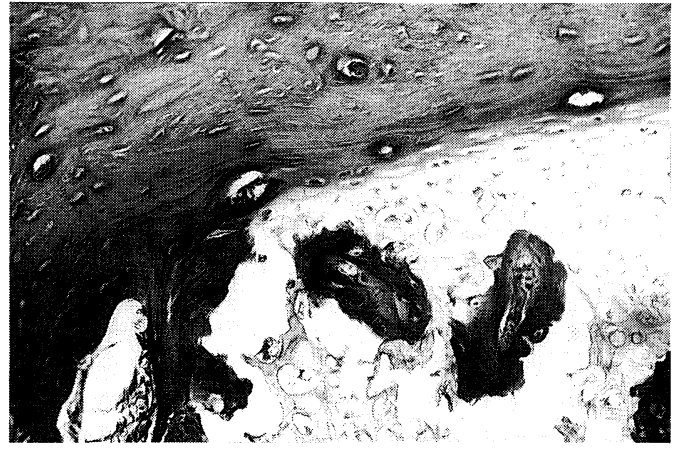

Fig. 11 Group II-60 days-Cartilage and newly formed bone. H.E. x160

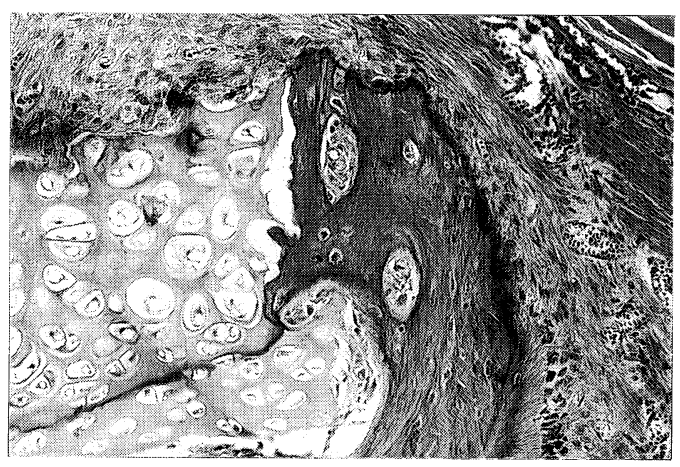

Fig. 12 Group I-120 days-Resorption of cartilage and substitution by newly formed bone. $\mathrm{H}$. E. $\times 160$ 


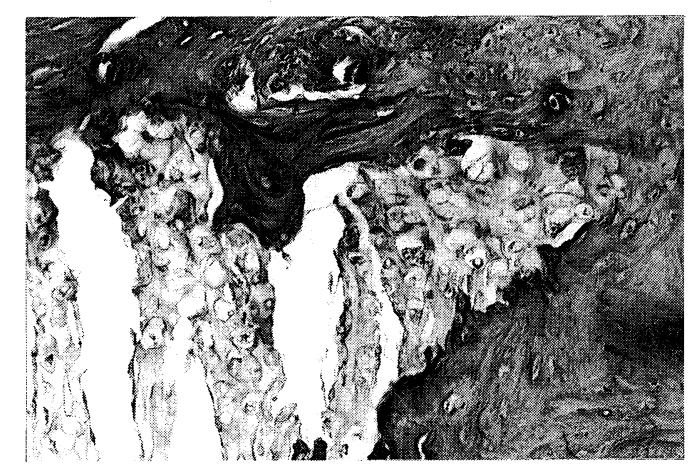

Fig. 13 Group II-120 days-Resorption of cartilage and substitution by newly formed bone. H.E. x160

specimens, approximately half the graft remained. A gradual increase was seen in newly formed bone, which filled the resorption lacunae (Fig.8), displaying thick and well defined trabeculae. At some points, fibrous connective tissue still remained.

60 DAYS

GROUP I - In most cases, a little more than one-third of the graft remained, and bone was in close contact with the cartilage, filling the resorption lacunae (Fig.9). At some of these sites, fibrous connective tissue separated the bone from the graft.

GROUP II-In some specimens, grafts showed little difference from the previous period for the same group. However, other specimens showed greater resorption, approximately one-third of the cartilage remaining. At several sites, bone was in contact with the graft, evenly filling the cavity (Figs. 10 and 11).

\section{DAYS}

GROUP I - In some of the specimens, a small amount of cartilage persisted (Fig.12), whereas in others it was totally absent. The surgical cavity was completely filled with thick and well defined osseous trabeculae.

GRUOP II - The presence of a small amount of cartilage was more frequent than in Group I (Fig.13). However, the remaining cartilage was totally infiltrated by thick and well defined bone trabeculae, which filled the surgical cavity.

\section{Discussion}

Preservation in glycerol reduces tissue antigenicity ${ }^{[13,19]}$, but does not eliminate it totally ${ }^{[16]}$. Autogenous cartilage preserved in glycerol undergoes faster resorption and bone substitution than fresh material, specially in areas where the perichondrium is removed ${ }^{[6]}$. Resorption rates of the homogenous material thus preserved are greater than those of autogenous material, possibly due to residual antigenicity ${ }^{[16]}$.

Allogeneic human cartilage preserved in $50 \%$ alcohol is also resorbed and substituted by fibrous tissue faster than autogenous tissue ${ }^{[7]}$. Cartilage preserved in $70 \%$ alcohol seems to show even greater rates of resorption and osteogenesis ${ }^{[8]}$. On the other hand, alcohol-preserved cartilage shows well defined osteogenic potential, both intrinsic and extrinsic to rat kidney transplanted material ${ }^{[20]}$.

The inflammatory reaction observed in the present study 5 days after surgery was similar for both methods of preservation, and was compatible with the late inflammatory phase of surgical trauma.

After 10 days, resorption of the cartilage was seen in both groups. This resorption was more intense in the case of the alcohol-preserved material. SCARso FILHO et al. ${ }^{[16]}$ observed resorption of the extremities of glycerol-preserved cartilage grafts after 7 days. If the perichondrium is 
maintained, it will protect the transplanted cartilage from resorption, even if devitalized by preservation in glycerol ${ }^{[6]}$. Fresh allogeneic cartilage, transplanted into the same host bed, initiates its resorption process earlier ${ }^{[21]}$.

After 30 days postoperatively, resorption of the cartilage preserved in $70 \%$ alcohol was more intense. However, this pattern was not maintained, since the results after 60 and 120 days were similar. This suggests that the reduction of antigenicity by glycerol, as described by TANNURY et al. ${ }^{[13]}$ and $\mathrm{ZERBINI}^{[19]}$, may not be significant for this kind of material, or that the effects are not different from those resulting from $70 \%$ alcohol preservation. It is also possible that after the grafts have been reduced by resorption to a certain size, the preservation method no longer influences the process. Apart from these considerations, graft resorption occurred in a manner similar to that described in the literature ${ }^{[6,17,22-25]}$.

Thus, the present study showed no advantages of one method over the other, since the grafts were well tolerated in both cases and the resorption rates were the same after 60 days. However, larger grafts or other tissue grafts may behave differently.

\section{Conclusions}

1. Cartilage grafts preserved in $70 \%$ alcohol and $98 \%$ glycerol are equally well tolerated.

2. Resorption and bone substitution in the grafted cartilage are similar for both methods after 120 days, although resorption was greater for the alcohol-preserved cartilage for up to 30 days.

3. The possible reduction of antigenicity by the $98 \%$ glycerol produced no difference in behavior from $70 \%$ alcohol-preserved cartilage.

\section{References}

[1] Boyne, P. J.: Transplantation, implantation and grafts, Dent. Clin. North. Am., 15, 433-453, 1971

[2] Lye, T. L:: A histological evaluation of cartilage homograft implant used in preprosthetic surgery, Oral Surg. Oral Med. Oral Pathol., 31, 745-753, 1971

[3] Boyne, P. J. and Cooksey, D. E.: Use of cartilage and bone implants in restoration of edentulous ridges, $J$. Am. Dent. Assoc., 71, 1426-1435, 1965

[4] Goode, R. L.: Bone and cartilage grafts. Current concepts, Otolaryngol. Clin. North Am., 5, 447-451, 1972

[5] Alexander, J. M.: Alloplastic augmentation of middle third facial deformities, J. Oral. Surg., 34, 165-172, 1976

[6] Gabrielli, M. F. R., Okamoto, T., Marcantonio, E. and Barbosa, C. E. M.: Autogenous transplantation of rib cartilage, preserved in glycerol, to the malar process of rats. A histological study, J. Nihon Univ. Sch. Dent., 28, 87-99, 1986

[7] Peer, L. A.: The fate of living and dead cartilage transplanted in humans, Surg. Gynecol. Obstet., 68, 603610,1939

[8] Schaffer, E. M.: Cartilage transplants into the periodontium of rhesus monkeys, Oral Surg. Oral Med. Oral Pathol., 9, 1233-1246, 1956

[9] Pigossi, N.: Implantação de dura-máter homógena conservada em glicerina. Estudo experimental em cães, Arq. Cir, Clin. Exp., 27, 213-247, 1964

[10] Moraes, C. R., Tompson, G., Arruda, M., Lagreea, J. R, Cavalcanti, I., Victor, E., Escobar, M. and de Oliveira, M. D.: Correction of transposition of the great arteries using homologus dura mater. A preliminary report, Vasc. Surg., 11, 19-25,1977

[11] Lex, A. and RaiA, A.: O uso de dura-máter homóloga conservada em glicerina, no tratamento das hérnias incisionais, Rev. Paul. Med., 77, 123-128, 1977

[12] Puig, L. B., Verginelli, G., Kawabe, L., Melo, R., Conceição, A., Bittencout, D. and Zerbini, E. J.: Four years experience with dura mater cardiac valves, J. Cardiovas. Surg., 18, 247-255, 1977

[13] Tannuri, V., Pinto, V. C., Adde, F. C. and Maksoud, J. G.: Utilização de dura-máter homóloga em cirurgia pediátrica, Revta. Paul. Med., 92, 27-30, 1978

[14] Jatene, F. B., Assunção, L. F. P., Leone, E. C. A., Barros, M. M., Sipan, R. M. and Dias, A. R.: Estudo experimental da dura-máter quando interposta em traquéia de cães, Ars. cvrandi, 12, 23-39, 1979

[15] King Jr., J. H., McTigue, J. W. and Meryman, H. T.: A simple method of preservation of cornea for lamellar keratoplasty, Am. J. Ophthalmol., 53, 445-449, 1962

[16] Scarso Filho, J., Ramalho, L. T. O., Gabrielli, M. F. R. and Acetoze, P.: Transplante autógeno e 
homógeno de cartilagem hialina de costela, sem pericôndrio, preservada em glicerina, para o processo malar de ratos. Estudo hitológico, Araraquara, Faculdade de Odontologia, UNESP, Unpublished data, 1991

[17] Окамoto, T., Gabrielli, M. A. C., Oliveira Jr., O. B., Marcantonio, E. and Gabrielli, M. F. R.: Autogenous transplantation of rib cartilage preserved in glycerol, after removal of the perichondrium, to the malar process of rats. A histological study. (Part I ), J. Nihon Univ. Sch. Dent., 32, 116-126, 1990

[18] Schaffer, E. M. and PACKer, M. W.: Bone regeneration of cartilage and tooth grafts in periodontal pockets, The Dent. Clin. N. Am., 6, 459-469, 1962

[19] ZerbinI, E. J.: Results of replacement of cardiac valves by homologous dura mater valves, Chest, 67, 706710,1975

[20] Nigrisoli, P.: Experimenti di innesto di cartilage fissata nel rene e di sostituzione di parti scheletriche con cartilagine fissata, Arch. per le Sc. Med., 49, 689, 1927

[21] Gerlin, J. V., Barbosa, C. E. M., Marcantonio, E., Scarso Filho, J., Gabrielli, M. F. R. and Gabrielli, M. A. C.: Transplante autógeno e homógeno de cartilagem hialina de costela, sem pericôndrio, para o processo malar de ratos. Estudo histológico comparativo, Araraquara, Faculdade de Odontologia, UNESP, Unpublished data, 1991

[22] Peer, L. A.: Transplantation of Tissue: Cartilage, Bone, Fascia, Tendon and Muscle, 1st ed., Vol. 1, 421, Baltimore, Williams and Wilkins, 1955

[23] Brown, K. L. and Cruess, R. L.: Bone and cartilage transplantation in orthopaedic surgery. A review, $J$. Bone Joint Surg. Am., 64, 270-279, 1982

[24] Túlıo, S.: Enxerto autógeno livre de cartilagem hialina com e sem pericóndrio em processo malar de ratos. Estudo histológico, Araçatuba, Doctorate Thesis, Faculdade de Odontologia, UNESP, 1984

[25] Gabrielli, M. F. R.: Transplante autógeno de cartilagem hialina, conservada em glicerina, para o arco zigomático do rato. Estudo histológico, Araçatuba, Doctorate Thesis, Faculdade de Odontologia, UNESP, 1985 